\title{
Monitoring the effects of pastoral use on upland and high country soils in South Island, New Zealand
}

\author{
P.D. McINTOSH', R.B. ALLEN', R. PATTERSON ${ }^{2}$, B. AUBREY ${ }^{3}$ and P. McGIMPSEY ${ }^{4}$ \\ ${ }^{1}$ Landcare Research, Private Bag 1930, Dunedin \\ ${ }^{2}$ Longview, 5KRD, Oamaru \\ ${ }^{3}$ Glencaim Station, Private Bag, Omarama \\ ${ }^{4}$ Ravensdown Fertiliser Cooperative, PO Box 179, Alexandra
}

\section{Abstract}

This paper reports on chemical changes that have occurred since 1978 in topsoils (O-7.5 cm depth) of upland and high country farms at 3 sites: Longslip and Glencaim Stations near Omarama, north Otago, and the east Otago uplands between Middlemarch and Alexandra. Between 1978 and 1992 on Longslip, on fertilised and oversown hilly and steep slopes, mean soil organic $\mathrm{C}$ increased by $67 \%$, total $\mathrm{N}$ value changed little, and $\mathrm{pH}$ declined by 0.41 units. Associated with the soil changes were declines in the amount of bare ground and snow tussock cover, and increases in legume and hieracium cover. The organic $\mathrm{C}$ change was equivalent to an increase of about $11 \mathrm{t}$ C/ha between 1978 and 1992. Over the same time period no topsoil changes on lower landscape positions were apparent. On Glencairn, under grazing but no topdressing, mean organic $\mathrm{C}$ declined by $10 \%$, total $\mathrm{N}$ declined by $25 \%$ and $\mathrm{pH}$ declined by 0.43 units-between_1978_and_1993. The organic C and $\mathrm{N}$ changes were equivalent to a decline of about $1.7 \mathrm{t} \mathrm{C} / \mathrm{ha}$ and $0.4 \mathrm{t} \mathrm{N} / \mathrm{ha}$ between 1978 and 1993. In contrast, within unfertilised and fertilised plots of exclosures that had not been mown or grazed for 9 years, organic $\mathrm{C}$ rose by $40-55 \%$, total $\mathrm{N}$ rose by $21-36 \%$, and there was no significant change of pH. Vegetation changes outside the exclosures included an increase of hieracium and briar cover. On the east Otago uplands under light grazing and little or no fertiliser application no significant changes of $\mathrm{pH}$, organic $\mathrm{C}$ or total $\mathrm{N}$ were-recorded between 1978 and 1994. The results show that soil monitoring can give useful information about the changes associated with pastoral use and the options available to maintain or enhance soil organic matter and $\mathrm{pH}$ levels.

K eywords: high country, monitoring, organic C, $\mathrm{pH}$, sustainability, total $\mathrm{N}$

\section{Introduction}

The 1970s and early 1980s were a time of agricultural development. However, the withdrawal of cheap loans and subsidies in the 1980s, concurrent with periodic explosions of rabbit populations and the invasion of weeds like hieracium and briar, has raised the issue of the sustainability of high country pastoralism (Hughes 1990). The ability of high country soils to support sustained pastoralism has been brought into question by O'Connor \& Harris (1991) who calculated that $\mathbf{1 5 0}$ years of pastoralism has caused substantial losses of the four major nutrients $(\mathbf{N}, P, K, S)$ throughout the high country. The declining ability of soils to support productive pastures was a major issue shaping the recommendations of the High Country Review (Martin et al. 1994). Although assessments of soil changes are crucial to arguments about sustainability of pastoral land use, there have been few long- or medium-term studies of soil changes on individual farms. This paper reports on farm-scale soil changes since 1978 at three upland and high country locations.

\section{Study areas and characteristics}

The Longslip study area is a hilly and steep spur with strong aspect contrast at 685-1 $190 \mathrm{~m}$ altitude south of the Ahuriri River. $25 \mathrm{~km}$ west of Omarama, North Otago. Mean annual rainfall is $700-1000 \mathrm{~mm}$. Soils are Brown Soils and Pallic Soils previously mapped in the Kaikoura and Omarama sets.

The Glencaim study area is a hilly and steep spur with strong aspect contrast at $440-810 \mathrm{~m}$ altitude on the east side of the Benmore Range, $25 \mathrm{~km}$ north-west of Omarama. Mean annual rainfall is 500-600 mm. Soils are Pallic Soils previously mapped in the Meyer and Omarama sets.

The east Otago uplands study area is rolling land at 700-I $100 \mathrm{~m}$ altitude between Middlemarch and Alexandra, and has a rainfall of about 700-I $100 \mathrm{~mm}$. Soils are Brown Soils previously mapped in the Teviot set. 
Precise locations and characteristics of the study areas are given by McIntosh et al. (1981) and McIntosh \& Backholm (1981). NZ Soil Bureau (1968) gives the general soil pattern at each location and McIntosh et al. (1981, 1983) describe the soils in detail.

In 1980 the Longslip area was oversown with clovers and grasses and between 1980 and 1992 a total of 1100 $\mathrm{kg} / \mathrm{ha}$ of S-superphosphate (28\% total S) was applied. The Glencaim area soils have not been oversown or topdressed. On the east Otago uplands'the amount of fertiliser applied is not accurately known but the presence of clovers at only one site in 1978 but at 11 of the 26 sites revisited in 1994, indicates that at these sites light topdressing, probably at the rate of about $250 \mathrm{~kg} / \mathrm{ha}$ of single superphosphate (a standard initial rate for legume establishment), has occurred at least once.

No lime has been applied on Longslip or Glencairn and is most unlikely to have been applied on the east Otago uplands, where it is standard practice to spread lime only after cultivation.

\section{M ethods}

On both Longslip and Glencaim, soils were grid sampled $(0-7.5 \mathrm{~cm}$ depth) on slopes with strong aspect contrast. Stock camps were avoided. There were 38 sites on Longslip and 24 sites on Glencaim. At most sites soils were sampled in 1978, but a few were sampled in 1979. The same sites were resampled in 1992 and 1993 on Longslip and in 1993 on Glencaim. Details of sampling method are given by McIntosh et al. (1981, 1994).

On Glencaim stock- and rabbit-proof fertiliser trial areas (McIntosh et al. 1985; Boswell \& Swanney 1990) have effectively functioned as exclosure plots since 1979. Trial plots were oversown in 1979 and mown (with clippings discarded) between the 1979 and 1984 seasons but afterwards not mown or grazed. Unfertilised control plots and plots fertilised twice with $370 \mathrm{~kg} / \mathrm{ha}$ of S-superphosphate (27\% total S) were sampled in 1993 for the present study.

On the east Otago uplands 26 sites near the Old Dunstan and Lake Onslow Roads were sampled in 1978 and 1994 by the methods described by McIntosh \& Backholm (1981).

Soils were analysed by standard methods used at Invermay Agricultural Centre. Longslip 1993 samples were analysed for $\mathbf{p H}$ only. Differences in soil chemistry values between 1978 and 1992/93/94 sampling dates were analysed by paired t-test.

Longslip and Glencaim sites were sampled for bulk density in 1994 so that soil changes could be estimated on a weight per hectare $(\mathrm{kg} / \mathrm{ha})$ basis. Bulk density was calculated from the weight of oven-dried $\left(110^{\circ} \mathrm{C}\right)$ 0-7.5 $\mathrm{cm}$ soil, after removal of roots and stones ( $>2 \mathrm{~mm}$ ), bulked from 30 cores of known volume from each of the 62 sites. Because soil bulk density was not measured in 1978, changes of organic $\mathrm{C}$ and total $\mathrm{N}$ on a weight per hectare basis were estimated by applying 1994 bulk density values for each site to both 1978 and later soil analyses.

\section{Results}

Soil chemical changes are summarised in Figure 1.

On Longslip the $\mathbf{p H}$, organic $\mathrm{C}$ and total $\mathrm{N}$ changes since 1978 were described by McIntosh et al. (1994). Organic $\mathrm{C}$ increased significantly $(\mathrm{P}<0.001)$ by $67 \%$ (from 3.3\% C to 5.5\% C) between 1978 and 1992, the increase being larger on sunny slopes than on shady slopes. The small overall increase of total $\mathrm{N}$ over this time period was not significant $(\mathbf{P}<0.05)$ but there was a significant $(\mathrm{P}<0.01) 13 \%$ decline of total $\mathrm{N}$ on shady slopes and a significant $(\mathrm{P}<0.05) 26 \%$ increase of total $\mathrm{N}$ on sunny slopes. $\mathrm{pH}$ declined significantly $(\mathrm{P}<0.001)$ by 0.41 units, from 5.81 to 5.40 , the $\mathrm{pH}$ decline being similar on both aspects. These soil changes were associated with a decline in the amount of bare ground and snow tussock cover, and an increase in legume cover and sites with hieracium (McIntosh et al. 1994). In contrast, at 7 sites on lower landscape units under similar management, there was a slight decline of organic $\mathrm{C}$ and total $\mathrm{N}$ and no change in $\mathrm{pH}$ (McIntosh et al. 1994).

Mean bulk density on Longslip was $0.69 \mathrm{t}^{\mathbf{3}}$ on both sunny and shady slopes. The organic $\mathrm{C}$ changes are equivalent to an organic $\mathrm{C}$ increase of about $11 \mathrm{t} /$ ha (from 17 tha to 28 tha) between 1978 and 1992, the increase on sunny slopes (15 t/ha) being greater than the increase on shady slopes (6 t/ha). The total $\mathrm{N}$ changes are equivalent to a total $\mathrm{N}$ increase from $1.4 \mathbf{t}$ ha to $1.7 \mathrm{t} /$ ha on sunny slopes and a total $\mathrm{N}$ decline from $1.4 \mathrm{t}$ tha to $1.2 \mathrm{t}$ /ha on shady slopes. (All values are approximate because bulk density was not measured in 1978.)

On Glencaim mean organic C was 2.3\% in 1978. Under grazing but no topdressing (+G-F in Figure 1) organic $\mathrm{C}$ declined significantly $(\mathrm{P}<0.01)$ by $10 \%$ between 1978 and 1993. The decline was larger on sunny slopes $(20 \%)$ than on shady slopes $(4 \%)$. so that 1993 organic $\mathrm{C}$ was $1.5 \%$ on sunny slopes and $2.6 \%$ on shady slopes. Total $\mathrm{N}$ declined significantly $(\mathrm{P}<0.001)$ by $25 \%$ over this time period, from $0.24 \% \mathrm{~N}$ to $0.18 \%$ $\mathrm{N}$, the percentage decline being similar on both sunny and shady slopes. pH declined significantly $(\mathbf{P}<0.001)$ by 0.43 units, from 6.30 to 5.87 . In contrast, within exclosures that had not been cut or grazed for 9 years $(-\mathrm{G}+\mathrm{F}$ and $-\mathrm{G}-\mathrm{F}$ in Figure 1), there was no significant $(\mathbf{P}<0.05)$ change of $\mathbf{p H}$ on fertilised or unfertilised 


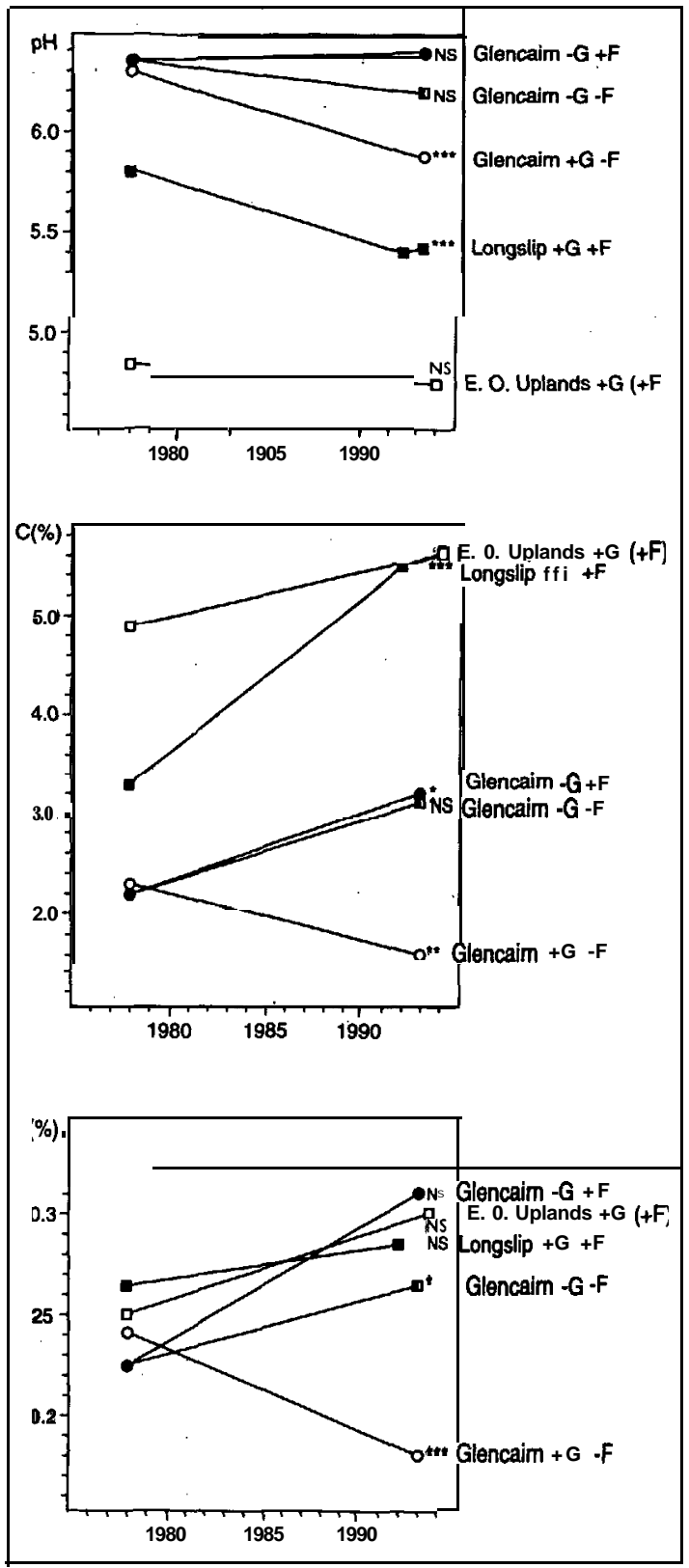

Figure 1 Mean changes of $\mathrm{pH}$, organic $\mathrm{C}$ and total $\mathrm{N}$ in topsoils $(0-7.5 \mathrm{~cm})$. For clarity, points are linked by straight lines, but changes may not have been linear. $+\mathbf{G}=$ with grazing; $-\mathrm{G}=$ no grazing for 9 years; $+\mathbf{F}=$ with fertiliser $(\mathbf{S}+\mathbf{P}$ plots as described in text); $(+F)$ light topdressing at some sites; $-\mathrm{F}=$ no fertiliser. Significance levels relate to differences between 1978 and 1992, 1993, or 1994 values within treatments linked. by lines: $*=$ $\mathbf{P}<0.05, * *=\mathrm{P}<0.01, * * *=\mathbf{P}<0.001 ; \mathrm{NS}=$ not significant. plots, organic $\mathrm{C}$ rose by $40-55 \%$, and total $\mathrm{N}$ rose by 21-36\%, but only the $\mathrm{N}$ rise on $-\mathrm{G}-\mathrm{F}$ plots and the $\mathrm{C}$ rise on $-\mathrm{G}+\mathrm{F}$ plots was significant $(\mathbf{P}<0.05)$.

Soil changes outside the exclosures were associated with an increase in the proportion of hieracium and briar cover (R.B. Allen, unpublished data). Soils under hieracium patches were on average more acid by $0.5 \mathrm{pH}$ unit than soils under native vegetation sampled on the same date (McIntosh \& Allen 1993).

Mean bulk density on Glencaim was $0.94 \mathrm{t} / \mathrm{m}^{3}$ (1.04 $\mathbf{t} / \mathbf{m}^{\mathbf{3}}$ on sunny slopes, $0.84 \mathbf{t} / \mathbf{m}^{\mathbf{3}}$ on shady slopes). The organic $\mathrm{C}$ changes are equivalent to an overall organic $\mathrm{C}$ decline from 15.8 tha to 14.1 tha between 1978 and 1993, the decline being greater on sunny slopes (2.7 t/ha) than on shady slopes $(0.7 \mathrm{t} / \mathrm{ha})$. The total $\mathrm{N}$ changes are equivalent to a total $\mathrm{N}$ decline from 1.8 tha to 1.4 tha on shady slopes and a decline from 1.4 tha to 1.1 t/ha on sunny slopes. (As previously mentioned, values are approximate.)

On the east Otago uplands mean $\mathrm{pH}$ of soils was 4.66 in 1978 and 4.74 in 1994, organic C increased from $5.1 \%$ in 1978 to $5.9 \%$ in 1994 . and total $\mathrm{N}$ rose

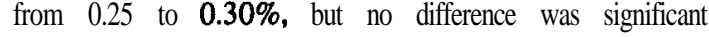
$(P<0.05)$.

\section{Discussion}

\section{Longslip}

McIntosh et al. (1994) found that the $\mathrm{pH}$ declines noted on Longslip were approximately those to be expected from regression equations relating $\mathbf{p H}$ decline to amount - of-dry-matter-produced ${ }^{-}$and ${ }^{-}$the $^{-}$rate $^{-}$of $^{-}$elemental $^{-} S$ applied (McIntosh et al. 1985). Linear regression of $\mathrm{pH}$ change against organic matter change implicated organic $\mathrm{C}$ accumulation in the process of $\mathbf{p H}$ decline on Longslip. $\mathrm{pH}$ decline could also be occurring through the process of $\mathrm{N}$ leaching (Sinclair et al. 1994).

The increase of soil organic $\mathrm{C}$ is attributed largely to the much greater dry matter production of fertilised pastures compared to production in unimproved pastures and reduced organic matter mineralisation under the improved vegetation cover. (The fertiliser rates used on Longslip would result in dry matter production approximately five to ten times higher than production from non-fertilised pastures.) The only alternative means for increasing organic carbon inputs to topsoil would he greater dry matter production as a result of higher rainfall, but the mean annual rainfall in the Ahuriri valley in the 7 years up to and including 1978 was 788 $\mathrm{mm}$, only slightly less than the mean of $832 \mathrm{~mm}$ in the seven years up to and including 1992, and both these figures are below the $898 \mathrm{~mm}$ mean for this rainfall station. Therefore a significant rainfall. influence on 1992 organic C values on Longslip is discounted. 
The organic $\mathrm{C}$ increase and less bare ground (than in 1978) on Longslip will aid moisture retention and provide greater resistance against erosion. The decline of total $\mathrm{N}$ on shady slopes possibly indicates transfer of $\mathrm{N}$ from shady slopes to stock camps.

\section{Glencairn}

The Glencaim data indicate that grazing alone (without fertiliser additions) affects topsoil chemistry, with sunny slopes being more prone to change than shady slopes. That organic $\mathrm{C}$ on Glencaim has declined to less than $2 \%$ in topsoils on sunny slopes indicates that these soils may now be more prone to degradation by wind and sheet erosion. We note that sunny slopes have organic $\mathrm{C}$ below the $2.5 \%$ minimum level for soil 'health' suggested by Parshotam \& Hewitt (1994).

Organic matter removal by grazing animals is considered to be a major influence on $\mathrm{C}$ and $\mathrm{N}$ values on Glencaim. The results from exclosures (Figure 1) show that eliminating grazing by sheep and rabbits arrests organic $\mathrm{C}$ and total $\mathrm{N}$ decline, but that to lift organic $\mathrm{C}$ and total $\mathrm{N}$ fertiliser application will be necessary. Whether organic $\mathrm{C}$ and total $\mathrm{N}$ would increase on Glencaim if pastures were to be grazed as well as fertilised could not be ascertained from the data collected, but the Longslip data indicates this might be so, in which case the restoration of organic matter can proceed with grazing. However, economic analysis indicates that, given present returns from wool, fertilising and oversowing the hilly and steep land on Glencaim to increase production is unprofitable.

The $\mathrm{pH}$ decline is attributed partly to a net cation loss through grazing, either by transfer of cations off the farm in animal products or to stock camps within the farm. Decline of exchangeable cations since 1978 has been established (Landcare Research, unpublished data). Locally hieracium also depresses pH (McIntosh \& Allen 1994).

\section{East $O$ tago uplands}

The limited sampling and analyses undertaken on the east Otago uplands indicate that soil changes over the last 16 years in this area have been slight. However, during sampling it was noted that hieracium cover (estimated visually) had increased and tussock cover had declined, and further vegetation and soil monitoring is advised before the sustainability of present farm practices is assumed.

\section{Conclusion}

The results show that soil monitoring can give useful information for assessing the sustainability of high country pastoralism and future options. Long-term monitoring on other sites with contrasting pastoral management is required to establish whether the reported trends are more widespread.

\section{ACKNOWLEDGEMENTS}

To Messrs T. Webb, G.G. Hunter, J. Arand, G. Ogle, Dr A. Mackay and Prof. K. O'Connor for comments on drafts of the manuscript. To $\mathrm{Mr} \mathrm{K}$. Bechler and $\mathrm{M}$. Loseke (Karlsruhe University) for assistance with soil sampling and bulk density determination. To staff of the analytical laboratory, Invermay Agricultural Centre, for soil analyses. The work was funded by the Foundation for Science, Research and Technology.

\section{REFERENCES}

Boswell, CC.; Swanney, B. 1990. Comparison of the long-term effects of different sulphur fertilisers on legume pasture production on a toposequence of North Otago Soils, New Zealand. NZ journal of agricultural research 34: 95-104.

Hughes, H. 1991. Sustainable land use for the dry tussock grasslands in the South Island. Office of the Parliamentary Commissioner for the Environment.

Martin, G.; Garden, P.; Meister, A.; Penno, W.; Sheath, G.; Stephenson, G.; Urquhart, R.; Mulcock, C.; Lough, R. 1994. South Island High Country Review. Final report of the working party on sustainable land management, April 1994. South Island High Country Review Working Party, Wellington. $184 \mathrm{p}$.

McIntosh, P.D.; Allen, R.B. 1994. Soil pH declines and organic carbon increases under hawkweed (Hiera-cium pilosella). NZ journal of ecology 17: 59-60.

McIntosh, P.D.; Backholm, G. 1981. A Reconnaissance Soil Survey of the Otago Uplands. Invermay Agricultural Research Centre Technical Report 10, 94 pp.

McIntosh, P.D.; Sinclair, A.G.; Enright, P.D. 1985. Responses of legumes to phosphorous and sulphur fertilisers on 2 toposequences of North Otago soils, New Zealand. NZ journal of agricultural research 28: 505-515.

McIntosh, P.D.; Backholm, G.; Smith, J. 1981. Soil variation related to landscape and vegetation features in North Otago hill country. NZ journal of science 24: $225-244$.

McIntosh, P.D.; Lee, W.G.; Banks, T. 1983. Soil development and vegetation trends along a rainfall gradient on the east Otago uplands. NZ journal of science 26: 379-401. 
McIntosh, P.D.; Allen, R.B.; Patterson, R.G. 1994. Temporal changes of vegetation and soil carbon, nitrogen and $\mathrm{pH}$ on seasonally dry high country, South Island, New Zealand. The rangeland journal (Australia) 16(1): 3-15.

NZ Soil Bureau 1968. General Survey of Soils of South Island, New Zealand. NZ Soil Bureau Bulletin 27.

O’Connor, K.F.; Harris, P.S. 1991. Biophysical and cultural factors affecting the sustainability of high country pastoral uses. pp. 304-3 13 in: Proceedings of the International Conference on Sustainable Land management, Napier, Hawkes Bay, New Zealand, 17-23 November 1991. (P.R. Henriques, Editor).
Hawkes Bay Regional Council, Napier, New Zealand.

Parshotam, A.; Hewitt, A.E. 1994. Modelling organic carbon in the Conroy land system of New Zealand. Proceedings of the International Congress on Modelling and Simulation (Perth, December 1993) (in press).

Sinclair, A.G.; Edmeades, D.C.; Ledgard, S.F. 1994. The influence of phosphorus, sulphur and nitrogen fertilisers on acidification in pastoral soils. Proceedings of the NZ Fertiliser Manufacturers Conference, Dunedin, New Zealand (1993) (in press). 